\title{
Penetapan Skala Industri Batik Rumahan Menurut Kriteria Lokal: Studi di Desa Jarum, Kabupaten Klaten
}

\author{
The Determination Of Batik Home Industry's Scale Based On Local Criteria: A Study in Jarum \\ Village, Klaten
}

\author{
Widhi Handayani ${ }^{1 *}$, Arianti Ina Restiani Hunga ${ }^{1}$, dan A. Ign. Kristijanto \\ ${ }^{1}$ Fakultas Pascasarjana Interdisiplin Universitas Kristen Satya Wacana \\ Jl. Diponegoro 52-60 Salatiga 50711 \\ ${ }^{2}$ Fakultas Sains dan Matematika Universitas Kristen Satya Wacana \\ Jl. Diponegoro 52-60 Salatiga 50711
}

\begin{abstract}
ABSTRAK
Kecamatan Bayat di Kabupaten Klaten sejak 1960-an menyuplai batik untuk keraton Yogyakarta dan Surakarta. Peran Bayat sebagai penyedia batik tidak terlepas dari desa Jarum yang ditetapkan sebagai desa wisata oleh Pemerintah Kabupaten Klaten pada tahun 2014. Mengingat batik diproduksi dengan POS atau Putting Out System yang mempekerjakan pekerja rumahan, kriteria skala industri yang diberlakukan untuk industri formal kurang tepat diterapkan pada industri batik sebagai industri berukuran mikro-kecil. Penelitian ini dilakukan untuk mendeskripsikan profil industri batik Jarum dan menyusun kriteria yang digunakan penduduk Jarum untuk menetapkan skala industri batik. Data penelitian kualitatif ini dikumpulkan dengan wawancara, observasi, dokumentasi, dan studi pustaka. Hasil penelitian menunjukkan ada 19 industri yang memproduksi kain batik, 10 industri memproduksi batik kayu, 1 industri memproduksi kaos batik, dan 1 industri memproduksi lukisan batik. Berdasarkan ukuran lokal, 7 industri dikategorikan besar, 13 industri dikategorikan sedang, dan 11 industri dikategorikan kecil. Kriteria yang digunakan untuk menetapkan skala industri adalah jumlah produksi, tenaga kerja, dan jangkauan pemasaran. Hanya 5 industri yang mengaplikasikan warna alam untuk menghasilkan kain, sedangkan pewarna sintetis diaplikasikan pada industri yang memproduksi kain, kaos batik, batik kayu, dan lukisan. Warna alam kurang diminati oleh juragan batik yang memakai pewarna sintetis karena memperlama produksi, jumlah produk terbatas, mutunya kurang terjamin, dan lebih sukar dipasarkan.
\end{abstract}

Kata kunci: batik, kriteria lokal, profil, putting out system, skala industri

\section{ABSTRACT}

Bayat Sub-district of Klaten Regency has been supplying batik to Yogyakarta and Surakarta since the 1960's. The role of Bayat as a batik provider is inseparable from Jarum village, which was officially established as a tourism village by the Government of Klaten Regency in 2014. Considering that batik is produced under Putting Out System (POS) which employs home workers, the industrial scale criteria applied to formal industry is less appropriate if it will be applied to batik home-industry as a micro-small scaled industry. This research was conducted to describe the profile of batik industry in Jarum village as well as arrange criteria used by Jarum people to determine the scale of batik industry. This qualitative research data was collected by interview, observation, documentation, and literature study. The results showed that there were 19 industries producing batik cloth, 10 industries producing batik woodcraft, 1 industry producing batik T-shirt, and 1 industry producing batik painting. Based on local perception, 7 industries were categorized as large, 13 industries were categorized as moderate, and 11 industries were categorized as small. The criteria used to establish the industrial scale were production scale, number of employees, and marketing reach. Only 5 industries found to apply natural colorants for batik clothes production, while synthetic dyes were applied broadly for batik clothes, batik T-shirt, batik woodcraft, and paintings. Natural colorants less desirable by batik Juragans who use synthetic dyes because the

\footnotetext{
*) Korespondensi:

Jl. Diponegoro 52-60 Salatiga 50711, Jawa Tengah;

+6281 325795 436; email: widhyandayani@gmail.com
} 
application of natural dyes will prolong the production, limits the scale of production, tend to shows uncontrolled quality, and more difficult to sell.

Key words: batik, local criteria, industrial scale, profile, putting out system

\section{PENDAHULUAN}

Batik Indonesia merupakan kekayaan budaya bangsa Indonesia, bahkan sudah ditetapkan sebagai Warisan Budaya Tak Benda oleh UNESCO. Secara ekonomi penetapan tersebut telah mendorong peningkatan ekspor batik ke mancanegara sekaligus menambah pendapatan bagi negara, serta meningkatkan lapangan kerja. Menurut Kementerian Perdagangan RI (2011), 99\% industri batik merupakan industri mikrokecil dan yang mendukung produksi batik untuk diekspor.

Berdasarkan daerah produksinya, batik dapat dibedakan menjadi dua, yaitu batik pesisiran dan batik pedalaman. Kota-kota di pantai utara Jawa sudah sejak lama memproduksi batik pesisiran, contohnya Pekalongan dan Lasem. Batik pedalaman dihasilkan oleh wilayahwilayah sekitar keraton seperti Surakarta maupun Yogyakarta. Salah satu daerah penyuplai batik untuk kedua wilayah keraton tersebut adalah Klaten. Sentra industri batik di Klaten berada di tiga kecamatan, yaitu Bayat, Wedi dan Juwiring. Bayat merupakan sentra batik terbesar karena terdiri atas 10 sentra industri, diikuti oleh kecamatan Juwiring dan kecamatan Wedi (Feriyanto, 2004). Sejak tahun 1960-an kecamatan Bayat sudah memproduksi batik untuk Surakarta. Bahkan menurut sejarahnya, perempuanperempuan pembatik yang tinggal di sini adalah pembatik-pembatik keraton (Ismadi, 2010).

Jika batik pesisiran terkenal dengan motif yang bebas dari pakem serta warna-warna terang menantang, maka batik pedalaman identik dengan pakem dan warna-warna kelam suram. Demikian pula batik Bayat yang kental dengan warna sogan, biru tua, dan hitam-putih. Meskipun motif yang dibuat adalah motif-motif klasik seperti Taruntum, Kawung, dan Parang, tak jarang para juragan membuat motif alas-alasan seperti dedaunan, bambu, dan beberapa jenis serangga. Juragan batik biasanya mengambil motif dari lingkungan sekitarnya, seperti Krambil Secukil dan Kopi Pecah yang menjadi motif khas Bayat (Ismadi, 2010).

Bayat tersohor sebagai penghasil batik bukan semata karena masa lalu, tetapi oleh karena ada desa Jarum yang menopangnya. Selain sebagai penghasil batik, Jarum telah ditetapkan oleh Pemerintah Kabupaten Klaten sebagai desa wisata sejak 2004. Wisata yang ditonjolkan di desa tersebut adalah wisata budaya untuk berlatih membatik, wisata belanja batik dan kerajinan lain, serta wisata alam (Harwanto, 2014).

Salah satu kekhasan batik Jarum adalah pada teknik pewarnaannya. Jika industri batik pesisiran menggunakan pewarna sintetis untuk menghasilkan nuansa warna terang, maka industri dulu kala batik di Jarum memproduksi batik dengan pewarna alami yang diperoleh dari tetumbuhan. Memang awalnya pewarnaan batik di masa lampau menggunakan pewarna alami, seperti dicatat oleh Raffles (2008), tetapi penemuan zat warna sintetis pada paruh abad ke19 telah mendorong diaplikasikannya secara besar-besaran untuk tekstil dan batik (Saravanan eta al., 2012). Kini dengan pelbagai pertimbangan seperti memelihara kesehatan dan lingkungan hidup, sedangkan aplikasi pewarna alami kembali diperkenalkan kepada dunia batik.

Mempelajari industri batik tentu memerlukan berbagai informasi terkait industri, setidaktidaknya mengenai skala dan sistem produksinya. Bicara tentang skala, selama ini industri dikategorikan besar-sedang-kecil menurut indikator industri formal berdasarkan omzet, modal, dan jumlah tenaga kerjanya. Persoalannya, batik diproduksi dengan POS yang mempekerjakan pekerja rumahan (Hunga, 2012; ILO, 2015). Para pekerja rumahan merupakan tenaga borongan atau tenaga kerja lepas yang bekerja di rumah-rumah. Jadi satu industri mikro-kecil batik bisa saja memiliki banyak tenaga kerja, dan artinya indikator yang diterapkan pada industri formal kurang sesuai untuk industri batik. Kriteria atau indikator menurut pelaku usaha batik menjadi penting untuk disusun guna menentukan skala industri. Itulah sebabnya penelitian ini dilakukan untuk mendeskripsikan profil industri batik yang ada di desa Jarum dan menyusun ukuran lokal untuk menetapkan skala industri batik. 


\section{METODE PENELITIAN}

Penelitian dilakukan di desa Jarum, Kecamatan Bayat, Kabupaten Klaten, Jawa Tengah. Kecamatan Bayat terdiri atas delapan belas desa, dan salah satunya adalah desa Jarum yang merupakan desa wisata batik.

Awalnya dilakukan pemetaan terhadap industri batik di desa Jarum. Data jumlah industri kami kumpulkan dari Dinas Perindustrian dan Perdagangan (Disperindagkop) Kabupaten Klaten, Lurah desa Jarum, dan penelitian terdahulu yang telah dilakukan di desa Jarum. Semua data dibandingkan untuk menetapkan jumlah industri yang masih produktif dan sudah tidak produktif. Konfirmasi status industri dengan cara menelepon pengrajin batik sebagaimana tercatat dalam daftar. Industri dikelompokkan menurut jenis batik yang diproduksi, seperti batik kayu, batik gerabah, atau kain batik. Data dikumpulkan untuk mengetahui profil industri, skala produksi, dan jenis pewarnaan yang diaplikasikan untuk produksi batik.

Berikutnya, data dikumpulkan untuk menentukan skala industri menurut indikator lokal atau indikator yang berlaku di desa Jarum. Data dikumpulkan dari 14 responden yang berprofesi sebagai Lurah, pengurus Paguyuban Batik desa Jarum, pemilik industri batik, serta agen penjualan atau tengkulak batik Jarum. Dua jenis data diperoleh pada tahap ini. Pertama, data skala industri-industri batik. Kedua, kriteria yang dipakai responden untuk menentukan industriindustri sebagai industri besar, sedang, atau kecil.

Selanjutnya dilakukan wawancara terhadap 10 juragan kain batik yang dianggap berskala besar-sedang-kecil menurut penilaian para responden. Wawancara tersebut dilakukan untuk menguji silang atau mengkonfrontasikan kecocokan kriteria yang dipakai responden dengan fakta-fakta di lapangan. Contohnya, jika kriteria lokal menetapkan industri batik dianggap kecil bila produksinya 30 potong kain perbulan, maka dilakukan wawancara terhadap juragan batik kecil untuk mendapatkan informasi mengenai skala produksi. Jadi pada tahap ini diperoleh data hasil uji silang dengan kriteria lokal. Data tersebut dianalisis sehingga dapat dikelompokkan skala industri besar-sedang-kecil menurut fakta di lapangan. Kedua jenis data, yaitu kriteria menurut persepsi responden, dengan fakta di lapangan kemudian disusun ulang menjadi kriteria penyesuaian. Data dikumpulkan dengan wawancara, studi pustaka, observasi, dan dokumentasi dan dianalisis secara deskriptif. Hasil disajikan secara naratif dan dalam tabel. Perlu ditambahkan bahwa beberapa nama yang dicantumkan dalam tulisan ini bukanlah nama sebenarnya, dan tindakan ini dilakukan untuk menjaga kerahasiaan responden.

\section{HASIL DAN PEMBAHASAN}

\section{Kain dan Kayu dalam Kenangan Pembatik}

Pemetaan yang dilakukan, ditemukan 31 industri batik di desa Jarum: 19 industri memproduksi kain batik, 10 industri memproduksi batik kayu, 1 industri memproduksi kaos batik, dan 1 industri memproduksi lukisan batik. Tidak ditemukan industri yang memproduksi batik gerabah di sini. Amatlah wajar jika banyak dijumpai industri yang memproduksi kain batik, karena memang sejak lama Jarum telah menjadi penghasil kain batik untuk kalangan keraton (Ismadi, 2010). Berikut dijelaskan profil seorang juragan kain batik.

Ibu Prapti (bukan nama sebenarnya, 68 tahun) telah memulai usaha batik sejak tahun 1968. Beliau tidak mengenyam pendidikan tinggi dan saat masih muda pekerjaannya adalah berdagang beras keliling desa sambil mengayuh sepeda. Keinginan berdagang batik tumbuh karena ingin menyekolahkan anak-anaknya. Diperhatikannya bahwa di desa Jarum belum ada yang membuka usaha batik, jadi belajar membatik dan membuka usaha batik dengan dukungan bapaknya yang seorang guru. Dapat dikatakan bahwa Ibu Prapti adalah sosok yang mengawali usaha batik di desa Jarum (dedengkot batik Jarum, demikian sebutan Pak Bayan untuk Ibu Prapti). Tahun 1985 adalah masa keemasan baginya. Menurutnya, saat itu usaha batiknya dapat menghasilkan 500 potong kain perhari karena tenaga kerjanya masih banyak: bisa mencapai 600 orang. Para juragan batik yang kini ada di desa Jarum dulu adalah tenaga kerja Bu Prapti, demikian menurutnya.

Melalui usaha batik yang dirintisnya, Ibu Prapti dapat menyekolahkan kelima anaknya hingga menjadi sarjana dari tiga universitas negeri terkemuka di Indonesia. Bahkan ada seorang anaknya yang berhasil menempuh studi S2. Salah satu anaknya, lulusan Fakultas Hukum di universitas negeri bergengsi di Indonesia, pernah bekerja menjadi jaksa di Kalimantan, dan sempat mengenyam studi banding ke Amerika. Sang putri menikah dengan orang Perancis dan 
kini menetap di Dubai, Timur Tengah. Salah satu anaknya yang lain bekerja di Ungaran, sedangkan salah satu anaknya lagi bekerja menjadi karyawan di bank. Usia yang semakin tua menyebabkan Ibu Prapti meminta anak-anaknya untuk kembali ke desa dan melanjutkan usaha batik yang telah dirintisnya. Akhirnya seorang putrinya yang bekerja di bank bersedia mengundurkan diri dari pekerjaannya dan melanjutkan usaha batiknya di desa Jarum. Penerusnya itu telah menangani usaha batiknya selama kurang lebih 4 tahun.

Ibu Prapti saat ini memproduksi 150 potong kain per hari, baik batik cap, batik tulis, ataupun kombinasi, dengan ukuran 2,5 $\mathrm{m} \times 1,15 \mathrm{~m}$. Ibu Prapti membeli kain dari Medari, Sleman untuk memproduksi batik. Bahan bakar yang digunakannya adalah kayu bakar sekitar 1 truk (1 rit) untuk satu bulan produksi, yang dibelinya seharga satu juta rupiah. Kayu bakar tersebut digunakan untuk nglorod (meluruhkan lilin). Untuk merebus obat, digunakanlah bahan bakar dari gas dari tabung $12,5 \mathrm{~kg}$. Air diperolehnya dari sumur bor dan selama ini masih sangat cukup untuk mendukung produksi. Beliau tidak pernah memperhitungkan berapa banyak air untuk produksi, tetapi untuk mengolah air limbah akan mendapat bantuan IPAL (Instalasi Pengolahan Air Limbah) dari Pemerintah Kabupaten, yang akan ditanam di lahan seluas $14.000 \mathrm{~m}^{2}$ miliknya.

Batik yang diproduksi Ibu Prapti dibuat mula-mula dengan memotong kain yang kemudian direbus atau diobati supaya patinya larut. Selanjutnya kain digambar dengan motifmotif tertentu. Pembuat gambar atau motif saat ini adalah Ibu Prapti dan putrinya. Setelah digambar, kain dibatik tulis (dicanthing), dan diwarnai. Dulu menggunakan pewarna alam dan sintetis untuk mewarnai kain batiknya. Sekarang, karena pewarna alam hanya diminati oleh sedikit orang dan harganya mahal, maka lebih fokus membuat batik dengan pewarna sintetis yang harganya lebih murah dan peminatnya banyak.

Pembatikan (nyanthing) dilakukan oleh kurang lebih 100 tenaga kerja, terdiri atas 22 orang tenaga kerja tetap di rumah produksi dan sisanya adalah tenaga borong lepas. Ibu Prapti juga memiliki tenaga kerja di Solo, khususnya untuk proses finishing. Buruh perempuan diupah Rp50.000/hari, sedangkan yang laki-laki Rp75.000/ hari. Beda pengupahan dilakukannya karena pekerjaan buruh laki-laki dianggapnya lebih berat ketimbang buruh perempuan. Upah buruh borong lepas ditentukan pula oleh jenis kain yang dibatik. Jika kainnya sutra, pembatik dibayar Rp300.000/potong, tetapi jika kainnya katun, pembatik diupah Rp200.000/potong.

Batik produksi Ibu Prapti dipasarkan lewat kelima gerainya yang dibangun sejak 2012. Gerainya tersebar di rumahnya, Klaten, Wonosari, dan Ungaran (di rumah anaknya). Batik produksi Ibu Prapti juga dipasarkan secara online, terlebih sejak ditangani oleh putrinya. Batik produksinya sudah dipasarkan ke Jakarta, Yogyakarta, Solo, Bali, dan Surabaya.

Tantangan yang dirasakan oleh Ibu Prapti saat ini adalah mendapatkan lebih banyak modal dan tenaga kerja. Semakin banyak permintaan menuntut tingginya produksi yang harus diimbangi dengan lebih banyak modal. Perjuangan mencari tenaga kerja juga menjadi persoalan karena sekarang para pekerja membuka usaha sendiri. Akibatnya jumlah pekerja berkurang dan terjadilah persaingan antar juragan batik untuk mendapatkan tenaga kerja.

Selain kain batik, desa Jarum juga memproduksi batik kayu. Terhitung ada 10 industri yang produktif membuat batik kayu. Barang-barang yang diproduksi adalah peralatan rumah tangga seperti nampan, tempat tisu, dan piring kayu; aksesoris seperti gelang kayu; cenderamata seperti topeng kayu dan kalender kayu; dan mainan tradisional seperti dakon. Berikut profil salah satu juragan batik kayu.

Ibu Suharti (bukan nama sebenarnya) berumur 35 tahun saat wawancara dilakukan. Beliau sudah menikah dan memiliki 4 anak. Anak sulungnya sudah duduk di kelas XI SMA. Menurutnya, usaha batik sudah lama berkembang di Jarum, meliputi batik kain dan kayu. Namun sekarang makin bervariasi menjadi batik gerabah dan batik kaca yang bisa ditemukan di desa Pagerjurang. Selain batik, kini juga sudah semakin banyak usaha yang dikembangkan di desa Jarum seperti usaha pembuatan roti dan cobek.

Usaha batik Ibu Suharti dirintis pada tahun 1995. Beliau dan suaminya memproduksi pelbagai jenis batik kayu, misalnya topeng, tempat tisu, nampan, mainan tradisional anak-anak seperti dakon, dan cenderamata pernikahan. Topeng kayu tidak dibuatnya sendiri namun dibeli dari desa Pathuk, Kabupaten Gunungkidul, daerah yang telah terkenal dengan ukiran topeng kayunya. Topeng kayu polos yang telah dibeli kemudian dibatik sehingga menjadi topeng batik kayu. Jika topeng kayu dibeli dari luar desa, tempat tisu, cenderamata dan nampan dibuat 
sendiri di desa Jarum. Produk-produk tersebut dibuat dari berbagai jenis kayu, seperti kayu gamelina, kayu sengon putih, kayu albasia, kayu pule, dan kayu mangga.

Proses pembuatan batik kayu pada dasarnya sama dengan pembuatan batik pada media kain. Sebagai contoh, pembuatan batik topeng kayu mula-mula dilakukan dengan menggambar motif pada topeng kayu tersebut. Selanjutnya, topeng kayu dibatik (prosesnya disebut nglowongi) lalu diwarnai. Agak berbeda dengan pembuatan kain batik, bahan kimia yang digunakan untuk pewarnaan tentu saja khusus untuk kayu. Pewarnaannyapun tidak dengan cara mencelupkan topeng ke dalam larutan pewarna seperti yang lazim dilakukan untuk produksi kain batik, tetapi menyiramkan larutan pewarna ke topeng yang sudah dibatik. Setelah diwarnai, topeng kayu dibatik lagi dan sesudah tiga kali pewarnaan, topeng direbus untuk meluruhkan lilinnya.

Ibu Suharti tidak memperhitungkan secara terperinci jumlah produksi batik kayu per minggu karena jumlah produksinya ditentukan oleh ukuran produk. Semakin kecil ukuran barang, produksi batik kayunya bisa semakin banyak. Produksi batik kayu, menurut Ibu Suharti tidak banyak menghasilkan limbah dan tidak boros air. Sebagai contoh, untuk membuat 100 unit tempat tisu kubus, 10L air tidak habis digunakan. Larutan pewarnapun tidak pernah terbuang karena meresap ke dalam kayu. Ibu Suharti menambahkan bahwa di dusunnya para juragan batik hanya membuat satu sumur bor yang airnya digunakan secara bersama-sama untuk beberapa rumah tangga. Pemasaran produk Ibu Suharti dilakukan secara online. Beliau juga menerima pesanan. Batik-batik kayu buatannya telah dipasarkan ke Jakarta, Surabaya, Kalimantan, Bali, dan Australia.

Selain kain batik dan batik kayu, di desa Jarum juga dijumpai juragan batik yang memproduksi kaos batik. Meskipun sang juragan juga membuat kain batik, tetapi lebih mengutamakan produksi kaos batiknya.

Ibu Mardiyanti (bukan nama sebenarnya, 40 tahun) merintis usaha batik pada tahun 1994. Beliau menikah muda lalu menekuni usaha batik bersama-sama dengan kelima saudaranya. Saat itu masih belum banyak orang yang menekuni usaha batik sehingga peluang mendapatkan penghasilan dari batik masih cukup besar. Awalnya Ibu Mardiyanti dan suaminya hanya mengerjakan batik untuk hiasan dinding dan memiliki banyak konsumen dari Yogyakarta. Setelah krisis, penjualannya turun drastis hingga tersisa $10-20 \%$. Saat itu banyak pengrajin batik lain yang tutup karena produksinya "hanya ituitu saja". Masalah tersebut, membuat suami Ibu Mardiyanti berpikir "Batik apa ya, yang tidak hanya bisa dipakai oleh orang tua tapi bisa dikenakan oleh semua kalangan?". Memang saat itu batik cenderung identik dengan orang-orang tua; remaja dan anak-anak kurang tertarik mengenakannya. Akhirnya Ibu Mardiyanti dan suaminya memproduksi kaos batik, yang ternyata bisa diterima oleh pasar. Meskipun demikian, Ibu Mardiyanti tidak hanya memproduksi kaos batik, industri batiknya juga memproduksi hem, bed cover, dan lain-lain.

Ibu Mardiyanti sudah punya pasar sendiri. Salah satu pasarnya ada di Bali, yang sayangnya menurun drastis setelah peristiwa Bom Bali. Peristiwa tersebut menyebabkan usahanya turun hingga kurang lebih tinggal 30\%. Untunglah Ibu Mardiyanti dan suaminya juga sudah bekerja sama dengan Batik Kusumawicitra (bukan nama sebenarnya) selama sekitar 10 tahun, sehingga masih punya pelanggan. Ibu Mardiyanti memproduksi kaos batik tulis (bukan printing dan cap) karena pelanggan menghendaki batik tulis. Tetapi juga memproduksi batik tulis kombinasi cap dan tulis jika ada permintaan, misalnya untuk melayani pesanan seragam. Biasanya memproduksi kaos batik kombinasi yang alusan (halus) supaya bisa sesuai dengan anggaran pemesan.

Ibu Mardiyanti memproduksi 250 potong kaos batik perbulan. Kaos dibeli dari pabrik di Solo, masih tahap setengah jadi, dibatik per lembar, lalu dijadikan (finishing). Prosesnya mulamula menggambar pola pada kaos, kemudian kaos tersebut dibatik (nglowongi). Selanjutnya pola dasarnya ditutup dengan parafin, sedangkan motifnya dicolet sesuai dengan warna yang dikehendaki. Setelah itu, kaos dijemur sekitar lima menit sambil ditunggu, supaya lilin tidak meleleh. Langkah berikutnya adalah mencelupkan kaos ke dalam asam klorida $(\mathrm{HCl})$ encer untuk memunculkan warnanya. Setelah itu kaos dicuci bersih kemudian dijemur di tempat yang teduh. Jika sudah kering, motif yang sudah diwarnai tersebut ditutup dengan lilin, kemudian diwarnai dengan indigosol atau naftol, lalu direbus untuk meluruhkan lilinnya.

Ibu Mardiyanti menggunakan gas dan serbuk gergaji untuk bahan bakar, tidak 
menggunakan minyak tanah untuk produksi karena dalam sehari diperlukan tujuh liter minyak tanah dan harga minyak tanah Rp12.000 per liter dirasakannya cukup mahal. Beliau juga menggunakan gas $3 \mathrm{~kg}$ alih-alih gas $12,5 \mathrm{~kg}$ untuk membatik. Gas $3 \mathrm{~kg}$ bisa dipakainya selama 6 hari, padahal gas $12,5 \mathrm{~kg}$ hanya cukup untuk 12 hari produksi. Itulah sebabnya digunakan gas $3 \mathrm{~kg}$. Bahan bakar yang dipakainya untuk perebusan adalah serbuk gergaji dan kayu bakar. Suaminya telah membuat tungku dari semen dan serbuk gergaji dimasukkannya ke dalam tungku sehingga menurutnya panasnya bisa seperti gas.

Air diperoleh Ibu Mardiyanti dari sumur bor berkedalaman $56 \mathrm{~m}$. Selama ini tidak ada kendala untuk mendapatkan air, berbeda dengan saat masih menggunakan sumur gali. Pemerintah memang pernah menyediakan air dari sumur, namun karena harus membayar, warga tidak terlalu tertarik menggunakannya. Sekarang sudah banyak warga yang membuat sumur sendiri, sehingga sumur dari pemerintah kurang berfungsi. Dengan sumur bornya, air bisa digunakan untuk produksi dan kebutuhan seharihari, juga dibagikan kepada tetangga. Guna menampung air sumur, disediakan bak penampungan air berukuran $3 \mathrm{~m} \times 3 \mathrm{~m} \times 3 \mathrm{~m}$. Beliau tidak dapat memperkirakan berapa banyak air yang digunakan untuk produksi per hari. Prinsipnya setiap pagi mengisi penampungan air itu hingga penuh.

Ibu Mardiyanti melibatkan 30 orang tenaga kerja yang terdiri atas 15 tenaga borong lepas, dan 15 orang tenaga tetap. Upah tenaga borong lepas bervariasi antara Rp10.000-Rp100.000/potong untuk tiap lembar kaos. Para pekerja tetap mendapatkan gaji bulanan antara 1 juta-1,5 juta rupiah per bulan. Kaos batik produksi Ibu Mardiyanti selama ini dipasarkan di Yogyakarta, Solo, Jakarta, Kalimantan, dan Batam, bahkan pernah dipasarkan ke Italia pada 2009.

Ibu Mardiyanti dan suaminya telah menyediakan penampungan air limbah di belakang rumahnya sekitar 6 bulan berselang. Menurut Ibu Mardiyanti, lebih banyak limbah air cucian daripada limbah pewarna. Air limbah tersebut tercampur air hujan dan biasanya sudah habis sebelum mengalir sampai ke kebun. Ibu Mardiyanti menjelaskan pula bahwa sebelumnya air limbah industri batiknya telah diteliti oleh mahasiswa dari salah satu universitas di Yogyakarta, dan dinyatakan aman.
Kendala yang dihadapi oleh Ibu Mardiyanti adalah keterbatasan modal. Dengan kebutuhan Rp100.000/potong kain, diperlukan modal yang cukup untuk produksi. Terlebih beliau dan suaminya mengusahakan selalu ada pekerjaan untuk pegawai-pegawainya. Keduanya berprinsip lebih baik mempekerjakan sedikit tenaga kerja yang selalu mendapat pekerjaan, daripada mempekerjakan banyak tenaga kerja hanya dengan minim pekerjaan dan akhirnya kesulitan menghidupi pegawainya.

\section{Skala Industri Batik Menurut Ukuran Lokal}

Berdasarkan kriteria lokal, ke-31 industri batik dapat dibedakan menjadi industri berskala besar (7 industri), sedang (13 industri), dan kecil (11 industri). Studi selanjutnya difokuskan pada industri yang memproduksi kain batik. Selain jumlahnya paling banyak, produksi kain batik membutuhkan lebih banyak air ketimbang batik kayu dan lukisan batik.

Tabel 1. Industri kain dan kaos batik menurut skala dan pewarnaan

\begin{tabular}{clcc}
\hline No. & $\begin{array}{c}\text { Nama industri } \\
\text { batik }\end{array}$ & Skala & $\begin{array}{c}\text { Jenis } \\
\text { pewarna }\end{array}$ \\
\hline 1. & Nardho & Besar & Sintetis \\
2. & Unik & Besar & Sintetis \\
3. & Purwanti & Besar & Sintetis \\
4. & Murinda & Sedang & Sintetis \\
5. & Sekar Mawar & Besar & Sintetis \\
6. & Natural & Besar & Alami \\
7. & Suparman & Sedang & Alami \\
8. & Indri & Kecil & Alami \\
9. & Putri Kawung & Kecil & Alami \\
10. & Fitri & Sedang & Sintetis \\
11. & Umbul Kuncoro & Kecil & Sintetis \\
12. & Ellsa & Besar & Sintetis \\
13. & Sri Endah & Besar & Alami \\
14. & Edi & Kecil & Sintetis \\
15. & Sarino & Kecil & Sintetis \\
16. & Sihdi & Kecil & Sintetis \\
17. & Slamet & Kecil & Sintetis \\
18. & Harsiyem & Kecil & Sintetis \\
19. & Sudarji & Sedang & Sintetis \\
20. & Maritsa & Kecil & Sintetis \\
\hline & & &
\end{tabular}

Tabel 1 menyajikan data industri yang memproduksi kain dan kaos batik beserta dengan skala industrinya menurut indikator penduduk lokal. Ada 20 industri kain batik di desa Jarum dan dari ke-20 industri tersebut, ada 7 industri yang digolongkan besar, 4 industri sedang, dan 9 industri kecil. Berdasarkan pewarnaannya 5 industri mencelup dengan pewarna alami, sedangkan sisanya menggunakan pewarna sintetis. 
Responden mengandalkan tiga indikator untuk menetapkan skala industri batik sehingga dapat digolongkan sebagai besar, sedang, dan kecil. Ketiga indikator tersebut adalah: (1) jumlah produksi per bulan; (2) jumlah showroom fisik dan bukan showroom online; (3) jumlah tenaga kerja yang dipekerjakan oleh pemilik industri; dan (4) jangkauan pemasaran (Tabel 2).

Tabel 2. Skala industri batik menurut kriteria lokal

\begin{tabular}{|c|c|c|c|}
\hline \multirow{2}{*}{ Kriteria } & \multicolumn{3}{|c|}{ Skala industri untuk kategori } \\
\hline & Kecil & Sedang & Besar \\
\hline $\begin{array}{l}\text { Produksi/bulan } \\
\text { (potong) }\end{array}$ & $30-80$ & $200-800$ & $500-1600$ \\
\hline $\begin{array}{l}\text { Jumlah } \\
\text { showroom }\end{array}$ & $\begin{array}{c}\text { Tidak } \\
\text { ada }\end{array}$ & 1 & $\begin{array}{l}\text { Lebih } \\
\text { dari } 1 \\
\end{array}$ \\
\hline $\begin{array}{l}\text { Jumlah } \\
\text { tenaga kerja } \\
\text { (tetap \& lepas) } \\
\end{array}$ & $\begin{array}{c}\text { Kurang } \\
\text { dari } 5 \\
\text { orang }\end{array}$ & $\begin{array}{l}5-10 \\
\text { orang }\end{array}$ & $\begin{array}{l}\text { Lebih } \\
\text { dari } 10 \\
\text { orang }\end{array}$ \\
\hline $\begin{array}{l}\text { Jangkauan } \\
\text { pemasaran }\end{array}$ & $\begin{array}{l}\text { Dalam } \\
\text { negeri } \\
\text { (lokal) }\end{array}$ & $\begin{array}{c}\text { Dalam } \\
\text { negeri } \\
\text { (Indonesia) }\end{array}$ & $\begin{array}{c}\text { Dalam } \\
\text { dan luar } \\
\text { negeri }\end{array}$ \\
\hline
\end{tabular}

Berdasarkan kriteria tersebut, kami mengumpulkan data dari juragan batik besar, sedang, dan kecil. Data yang dikumpulkan meliputi jumlah produksi, jumlah showroom fisik, jumlah tenaga kerja, dan jangkauan pemasaran, selain informasi umum. Langkah ini dilakukan untuk menguji silang kriteria pada Tabel 2 . Setelah dikelompokkan, diperoleh karakteristik industri batik menurut kriteria lokal (Tabel 3).

Tabel 3. Karakteristik industri batik menurut kriteria lokal

\begin{tabular}{lccc}
\hline \multirow{2}{*}{ Kriteria } & \multicolumn{3}{c}{ Skala industri menurut kategori } \\
\cline { 2 - 4 } & Kecil & Sedang & Besar \\
\hline $\begin{array}{l}\text { Produksi/bulan } \\
\text { (potong) }\end{array}$ & $20-150$ & $200-240$ & $250-3750$ \\
\hline Jumlah showroom & 1 & 1 & $1-5$ \\
\hline $\begin{array}{l}\text { Jumlah tenaga } \\
\text { kerja (tetap \& } \\
\text { lepas) }\end{array}$ & $2-19$ & $5-10$ & $15-100$ \\
\hline $\begin{array}{l}\text { Jangkauan } \\
\text { pemasaran }\end{array}$ & $\begin{array}{l}\text { Dalam } \\
\text { negeri } \\
\text { (lokal) }\end{array}$ & $\begin{array}{c}\text { Dalam } \\
\text { negeri }\end{array}$ & $\begin{array}{c}\text { Dalam } \\
\text { dan luar } \\
\text { negeri }\end{array}$ \\
\hline
\end{tabular}

Industri batik merupakan industri nonformal, sehingga indikator formal yang diterapkan pada industri formal kurang sesuai untuk diterapkan pada industri batik. Jumlah produksi per bulan merupakan salah satu indikator yang tidak dijumpai pada kriteria formal, namun diungkapkan oleh informan. Sayangnya indikator tersebut tidak mungkin dipakai sebagai indikator tunggal untuk mengklasifikasikan skala industri batik, karena masih tumpang-tindih.

Contoh, menurut Tabel 2 suatu industri digolongkan berskala menengah atau sedang jika dapat memproduksi 200-800 potong produk perbulan. Tetapi jika suatu industri bisa memproduksi 600 potong kain sebenarnya dapat dikategorikan sebagai industri besar, karena industri besar mesti menghasilkan 500-1600 potong kain perbulan. Uji silang kriteria Tabel 2 dengan data pada Tabel 3 menunjukkan kekurangsesuaian untuk industri berskala sedang dan besar. Tabel 3 menunjukkan bahwa industri berskala sedang "hanya" memproduksi 200-240 potong kain dalam sebulan, tidak mencapai 800 potong kain sebagaimana diindikasikan pada Tabel 2. Selain itu, ada industri berskala besar yang memproduksi 250 potong kain (Tabel 3), yang dengan jumlah sekian itu tentunya lebih cocok untuk dikelompokkan sebagai industri berskala sedang. Dilatarbelakangi oleh tumpangtindih antara kriteria dan kenyata-an yang ditemukan itu, kami melakukan penyesu-aian kriteria. Hasilnya, kriteria untuk industri kecil adalah memproduksi kain maksimum 150 potong produk perbulan, industri berskala sedang memproduksi 151-249 potong kain perbulan, sedangkan industri besar memproduksi minimum 250 potong kain perbulan.

Indikator kedua yang dipakai responden untuk menetapkan skala industri batik adalah jumlah showroom. Showroom yang dimaksud oleh responden adalah showroom fisik dalam bentuk bangunan alih-alih showroom online. Data yang diperoleh juga menunjukkan kekurang-sesuaian antara pendapat responden dengan observasi dan informasi dari juragan batik. Umumnya industri kecil batik yang dijumpai belum memiliki showroom fisik karena masih merintis dan belum mempunyai stok barang. Walaupun demikian, ada industri berskala kecil yang sudah menyediakan showroom di rumah. karena industri tersebut sebenarnya berupa kelompok usaha bersama. Salah satu anggota kelompok tersebut menyediakan showroom untuk memamerkan batik produksinya dan anggota kelompok yang lain. Dengan demikian, kriteria jumlah showroom tampaknya lebih tepat untuk industri batik yang kepemilikannya bersifat pribadi.

Sebenarnya jumlah showroom kurang sepenuhnya dapat digunakan sebagai patokan. Memang showroom menunjukkan aset yang 
dimiliki juragan batik, tetapi kini dengan adanya pemasaran online, juragan batik dapat memamerkan dan menjual produk-produknya secara online. Jadi tidak perlu membangun banyak showroom fisik. Ada seorang juragan batik (yang dianggap juragan besar) yang hanya memiliki satu showroom fisik di rumahnya, tidak membangun lebih banyak showroom fisik karena merasa lebih sering mendapatkan pesanan secara online melalui surel dan media sosial. Kecanggihan teknologi informasi tampaknya akan mengurangi kebutuhan juragan batik untuk membangun showroom fisik.

Kriteria berikutnya adalah jumlah tenaga kerja. Dijumpai adanya kekurangsesuaian antara jumlah tenaga kerja pada industri batik (Tabel 3) dengan jumlah tenaga kerja dalam kriteria (Tabel 2). Hunga (2014) menjelaskan bahwa batik diproduksi oleh POS, sebuah sistem yang para pekerja (utamanya para perempuan) melakukan pekerjaannya di rumah, sementara pekerja yang dimaksudkan dalam industri formal adalah tenaga kerja yang bekerja di pabrik.

Tabel 2 menunjukkan bahwa industri yang dianggap kecil ternyata memiliki 19 tenaga kerja. Sama dengan kriteria kedua, industri yang berskala kecil tersebut sebenarnya merupakan usaha bersama yang terdiri atas beberapa orang. Selanjutnya mengumpulkan uang untuk membeli kain yang dibagikan kepada setiap anggota untuk dibatik dan diwarnai. Batik yang sudah jadi diberi label lalu dijual melalui seorang anggota yang ditunjuk menjadi koordinator pemasaran. Inilah alasan mengapa industri tersebut dianggap berskala kecil, karena jika dipecah sampai kepemilikan pribadi, jumlah produksi dan jumlah tenaga kerjanya belum mampu bersaing dengan industri yang lebih besar. Jadi sesungguhnya kriteria yang ditetapkan oleh responden berhubungan dengan kepemilikan usaha secara pribadi.

Jangkauan pemasaran rupa-rupanya juga menjadi indikator yang digunakan oleh informan untuk menetapkan skala industri. Industri batik yang dianggap besar biasanya sudah memasarkan produk-produknya hingga keluar negeri. Industri berskala sedang sudah dapat menjual produk keluar Jawa Tengah atau bahkan hingga keluar pulau Jawa, sedangkan industri skala kecil baru bisa memasarkan produknya ke sekitar desa Jarum, seperti ke Klaten, Solo, dan Yogyakarta. Berdasarkan data-data pada Tabel 2 dan Tabel 3 tersebut, akhirnya, dapat disusun indikator untuk menetapkan industri batik rumahan ke dalam kategori besar-sedang-kecil (Tabel 4). Perlu dicatat bahwa indikator tersebut hanya bersifat untuk memandu, dan lebih sesuai untuk industri dengan kepemilikan pribadi ketimbang dengan kepemilikan kolektif.

Tabel 4. Kriteria skala industri batik Jarum

\begin{tabular}{|c|c|c|c|}
\hline \multirow{2}{*}{ Kriteria } & \multicolumn{3}{|c|}{ Skala industri menurut kategori } \\
\hline & Kecil & Sedang & Besar \\
\hline $\begin{array}{l}\text { Produksi } \\
\text { perbulan } \\
\text { (potong) }\end{array}$ & $\begin{array}{c}\text { Maksimum } \\
150\end{array}$ & $151-249$ & $\begin{array}{l}\text { Minimum } \\
250\end{array}$ \\
\hline $\begin{array}{l}\text { Jumlah tenaga } \\
\text { kerja (usaha } \\
\text { pribadi) }\end{array}$ & $\begin{array}{c}\text { Maksimum } \\
5 \text { orang }\end{array}$ & $\begin{array}{l}6-10 \\
\text { orang }\end{array}$ & $\begin{array}{c}\text { Minimum } \\
11 \text { orang }\end{array}$ \\
\hline $\begin{array}{l}\text { Jangkauan } \\
\text { pemasaran }\end{array}$ & $\begin{array}{l}\text { Dalam } \\
\text { negeri } \\
\text { (lokal) }\end{array}$ & $\begin{array}{c}\text { Dalam } \\
\text { negeri } \\
\text { (Indonesia) }\end{array}$ & $\begin{array}{c}\text { Dalam } \\
\text { dan luar } \\
\text { negeri }\end{array}$ \\
\hline
\end{tabular}

\section{Profil Batik Jarum Berdasarkan Pewarnaan}

Menurut jenis pewarnaannya, batik Jarum diwarnai dengan pewarna sintetis atau pewarna alam. Pewarna alam biasanya hanya digunakan untuk produksi kain batik, sedangkan pewarna sintetis diaplikasikan secara luas untuk memproduksi kain batik, batik kayu, dan lukisan batik.

Tercatat ada 20 industri yang memproduksi kain dan kaos batik, dan dari sejumlah industri tersebut ada 15 industri yang memproduksi batik dengan pewarna sintetis (Tabel 1). Hanya 5 industri yang memproduksi batik dengan pewarna alami, tetapi bersedia membuat batik dengan pewarna sintetis jika ada pemesan yang menghendaki demikian. Batik yang diwarnai dengan pewarna sintetis menghasilkan nuansa warna yang atraktif dan beragam dan lebih murah ketimbang batik yang diwarnai dengan pewarna alami.

Membuat batik dengan pewarna sintetis sama dengan yang dijelaskan oleh Ibu Prapti dan Ibu Mardiyanti. Prinsipnya, mula-mula dibuat pola pada kain katun, kemudian pola besar tersebut dibatik. Selanjutnya dilakukan pewarnaan dengan pewarna sintetis. Teknik lukis dengan kuas (disebut teknik colet) digunakan untuk mewarnai pola-pola tertentu, seperti ditampilkan pada Gambar 1.

Naftol dan Indigosol umum dipakai untuk mewarnai batik. Setelah diwarnai, kain dijemur di bawah sinar matahari supaya warnanya terbentuk. Setelah itu kain direbus untuk meluruhkan lilinnya, lalu dicelup ke dalam pewarna untuk memberi warna dasar. Setelah dicelup, kain dijemur lagi lalu difiksasi dengan asam klorida encer supaya warnanya tidak luntur. Tahap 
terakhir adalah mencuci kain lalu menjemurnya (Gambar 2).

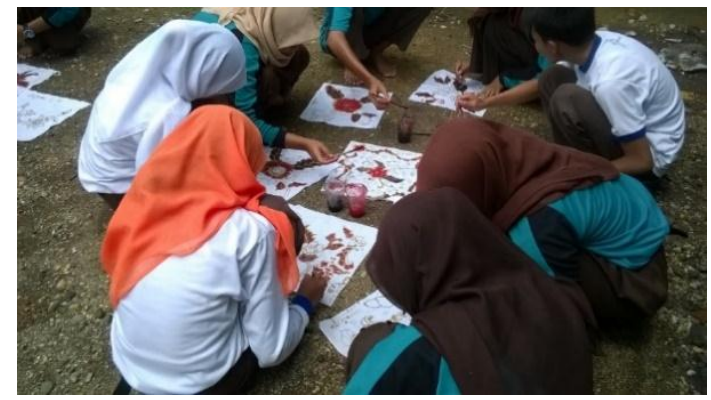

Gambar 1. Teknik nyolet batik dengan pewarna sintetis

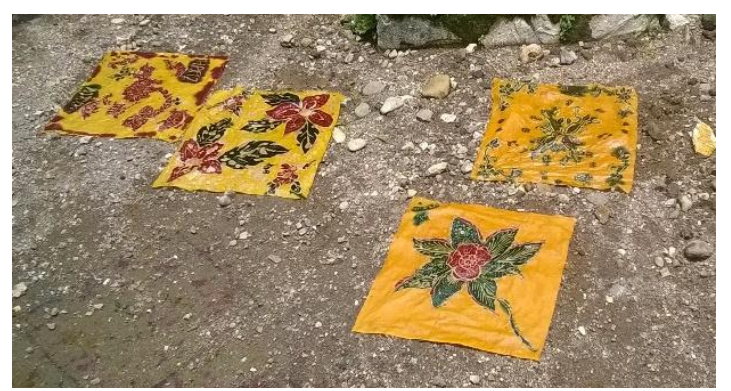

Gambar 2. Contoh batik yang diwarnai dengan pewarna sintetis

Pembuatan batik dengan pewarna alami pada prinsipnya sama dengan pewarnaan sintetis. Perbedaannya, pada pewarnaan alami pencelupan harus dilakukan berulang kali hingga mendapatkan warna yang diinginkan. Jika warna yang diinginkan sudah diperoleh, barulah dilakukan fiksasi atau pengikatan warna.

Meskipun ada juragan batik yang memakai pewarna alami, tetapi ada lebih banyak juragan yang membuat batik dengan pewarna sintetis. Para juragan tersebut (yang menggunakan pewarna sintetis) tidak atau belum mau beralih ke pewarna alami oleh beberapa pertimbangan. Pertama, ada pendapat bahwa batik warna alam hanya suatu euphoria. Saat ini batik warna alam memang menjadi trend, tetapi lama kelamaan akan surut juga karena harganya yang mahal. Harga batik warna alam yang mahal juga telah diungkapkan sebelumnya oleh Ibu Prapti sehingga tidak memproduksi lagi batik dengan pewarnaan alami.

Selain soal harga, warna batik warna alam juga dianggap kurang bertahan lama meskipun sudah difiksasi. Warnanya lama kelamaan memudar, demikian menurut pendapat seorang responden. Juragan juga merasa kurang tekun dalam menggunakan pewarna alami karena harus mengulang-ulang pencelupan. Terlebih jika benar-benar menggunakan pewarna alam, produksinya akan sangat terbatas karena mencelup berkali-kali membutuhkan waktu cukup lama. Singkatnya, batik warna alam memang memberikan tantangan tersendiri dalam produksi dan pemasarannya, sehingga kurang diminati oleh produsen batik warna sintetis.

\section{KESIMPULAN}

Industri batik di desa Jarum dapat dibedakan berdasarkan produk yang dihasilkannya. Ada 19 industri yang memproduksi kain batik, 10 industri memproduksi batik kayu, 1 industri memproduksi kaos batik, dan 1 industri memproduksi lukisan batik. Kain batik sudah dihasilkan sejak tahun 1960an di desa Jarum, tetapi kreativitas pembatik-pembatik generasi berikutnyalah yang menghasilkan kaos batik dan batik kayu. Berdasarkan standar lokal, dari 31 industri batik, terdapat 7 industri berskala besar, 13 industri berskala sedang, dan 11 industri berskala kecil. Tiga kriteria lokal yang dapat digunakan untuk menetapkan skala industri adalah jumlah produksi, jumlah tenaga kerja, dan jangkauan pemasaran. Industri batik di Jarum juga dibedakan menurut jenis pewarnaannya. Pewarna alam hanya digunakan oleh 5 industri yang memproduksi kain batik, sedangkan pewarna sintetis diaplikasikan secara luas pada industri yang memproduksi kain, kaos batik, batik kayu, dan lukisan. Penggunaan pewarna alami kurang diminati oleh juragan batik yang mengaplikasikan pewarna sintetis karena produksinya lebih lama, jumlah produk terbatas, mutunya kurang terjamin, dan lebih sukar dipasarkan.

\section{UCAPAN TERIMA KASIH}

Penulis mengucapkan terima kasih kepada Biro Perencanaan dan Kerjasama Luar Negeri, Kementerian Pendidikan dan Kebudayaan Republik Indonesia, yang telah mendukung penelitian ini melalui Beasiswa Unggulan Program Mandiri Tahun 2015 dengan SK Nomor 46287/A2.4/LL/2015. Ucapan terima kasih juga kami ucapkan kepada Kantor Kelurahan Desa Jarum, Kecamatan Bayat, Kabupaten Klaten, serta para responden yang telah memberikan informasi guna pelaksanaan penelitian ini. 


\section{DAFTAR PUSTAKA}

Feriyanto, N. 2004. Profil Industri Kecil Tekstil dan Produk Tekstil di Kabupaten Klaten. Jurnal Ekonomi Pembangunan, 9 (1): 91-104.

Harwanto, S. 2014. Kajian Wisata Seni Budaya Batik Berwawasan Lingkungan di Desa Jarum, Kecamatan Bayat, Kabupaten Klaten, Provinsi Jawa Tengah. [Tesis]. Institut Seni Indonesia, Yogyakarta.

Hunga, A.I.R. 2012. Menyingkap "Ketersembunyian" Home Workers dan Transformasi Putting Out System dalam Industri MikroKecil-Menengah Batik: Studi kasus klaster industri batik di Sragen-Surakarta-Sukoharjo. Satya Wacana University Press, Salatiga. ISBN 978-979-8154-50-8.

Hunga, A.I.R. 2014. Protecting Women's Domestic Area and Environment: Study on ecofriendly Batik. Indonesian Feminist Journal 2: 82-105.
International Labour Office. 2015. Penelitian tentang Praktik Pengusaha dalam Mempekerjakan Pekerja Rumahan di Provinsi Jawa Barat dan Jawa Tengah. ILO-ApindoIntercafe, Jakarta.

Ismadi, 2010. Batik Bayat Klaten: Tinjauan sejarah, bentuk, dan gaya. Fakultas Pendidikan Seni Rupa FBS. Universitas Negeri Yogyakarta, Yogyakarta. (11 Oktober 2014).

http://staff.uny.ac.id/sites/default/files/penelitia n/Ismadi,\%20S.Pd.,\%20M.A./2010_Batik\%20 Bayat.pdf.

Kementerian Perdagangan Republik Indonesia. 2011. Miliki Potensi Ekonomi Tinggi, Mendag Serahkan Cetak Biru Pengembangan dan Pelestarian Batik ke Presiden. Siaran Pers Kementerian Perdagangan Republik Indonesia (28 September 2011). Jakarta.

Saravanan, P., G. Chandramohan, S. Saivaraj. 2012. A Study on Eco-friendly Dye Obtained from Barks of Ficus religiosa. L on Cotton Fabric. World Journal of Applied Environmental Chemistry, 1(1): 30-34. 